\title{
AKABANE AND SCHMALLENBERG DISEASES: SIMILARITIES AND DIFFERENCES
}

\author{
E.G. Nikitina, N.I. Sal'nikov, E.O. Khan, E.A. Balashova, S.Zh. Tsybanov, D.V. Kolbasov \\ All-Russia Research Institute of Veterinary Virology and Mirobiology, Russia Academy of Agricultural Sciences, \\ Pokrov, Vladimir Region, 601120 Russia, \\ e-mail:VNIIVViM@niiv.petush.elcom.ru,balashowa.l@yandex.ru
}

\author{
Received May 6, 2013
}

\section{Su m mary}

The article describes the characteristics of Schmallenberg and Akabane viruses that cause disease in cattle, sheep and goats. Clinical symptoms of the diseases are described. The measures for the prevention, control and eradication of Schmallenberg and Akabane viruses are discussed. Despite the relationship of Schmallenberg and Akabane viruses and a similarity of the clinical picture and pathological changes, there are also differences. The first disease is more severe in sheep and goats than in bovine (cattle), with the viremia occurred at 1-4 days and 1-9 days (mostly 4-5 days) for Schmallenberg and Akabane viruses, respectively. Under Akabane virus infection, an encephalitis is observed in adult cattle, whereas such cases are not yet registered under the Schmallenberg disease. The authors have developed the test systems for detection of Akabane virus RNA by polymerase chain reaction and Schmallenberg virus genome by reverse transcription-polymerase chain reaction in real time (RT-PCR). For Akabane and Smallenberg viruses RNA detecting, a real time reverse transcriptase PCR-based tests have been developed by the authors.

Keywords: Schmallenberg virus, Akabane virus, cattle, sheep, goats, prevention and control.

Schmallenberg and Akabane diseases are zoogenous arbovirus infections of bovine cattle, sheep, and goats. Significant economic loss caused by these viruses result from lower milk yield, high incidence of miscarriage, still birth, and neonatal mortality in infected livestock. Causative agents of both diseases belong to serogroup Simbu of the genus Orthobunyavirus the family Bunyaviridae. Schmallenberg and Akabane viruses form spherical virions with diameters of 90-100 nm (1-3). Unlike other enveloped negative-strand RNA viruses, Bunyaviridae have no membrane or matrix protein, and nucleocapsid protein adjoins to the inner surface of the lipid bilayer (Fig. 1) (2-5). The remarkable fact is that viruses of this serogroup have never occurred in Europe (3).

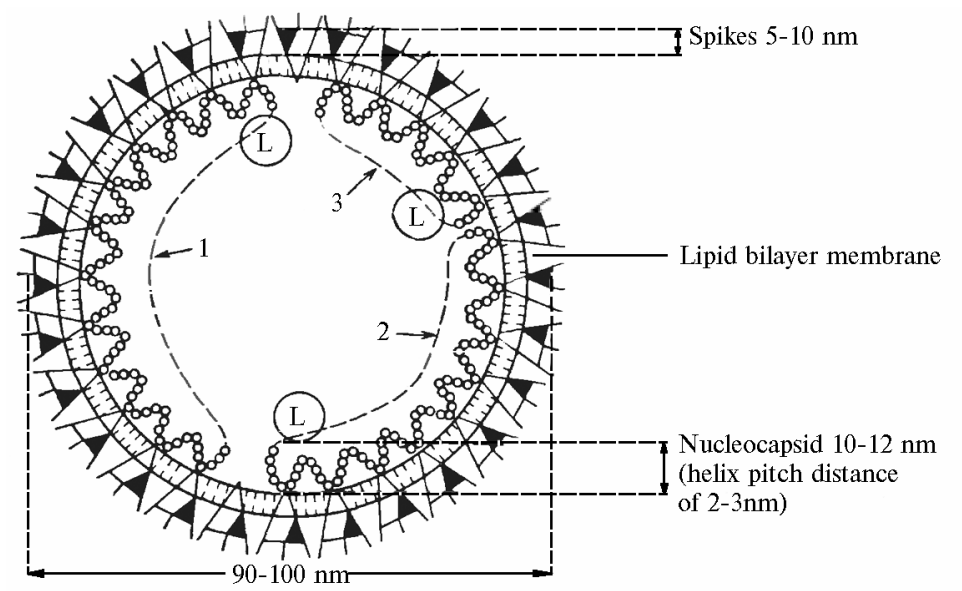

\author{
Fig. 1. Structure of Bun- \\ yaviridae virion:: 1,2 , and \\ 3 - respectively, long (L), \\ medium $(\mathrm{M})$, and small $(\mathrm{S})$ \\ segments of RNA genome as- \\ sociated with L-protein, (tran- \\ scriptase component)
}

Commonly, transmission of Schmallenberg and Akabane viruses is mediated by vectors - infected blood-sucking insects (mosquitoes and midges of the genera Culex, Aedes, and Sulicoides); it was also reported about intrauterine transmission from infected mothers to their progeny $(1,2)$. Duration of viremia of Schmallenberg disease is 1-4 days, Akabane - 1-9 days (usually 4-5 days).

There's an urgent problem linked to the credible threat of transmission of both infections into Russia with animals purchased from countries with infected livestock (from Europe - Schmallenberg disease), and various political, economic, tourist, and cultural relations with foreign countries (from Asia - Akabane disease). In Europe, Schmallenberg disease was recorded in 18 countries Germany, the UK, France, Spain, Italy, Austria, Denmark, the Netherlands, Belgium, Luxembourg, Switzerland, Sweden, Poland, Finland, Estonia, Ireland, Norway, and Scotland. This data is based on reported and confirmed cases (6), which just partly show actual spread of the disease because diagnostic studies hadn't been performed in all countries. The situation with Akabane disease is similar (in Asia, confirmed cases were recorded in Japan and Korea).

Schmallenberg disease in sheep and goats is expressed with more severe course than in cattle: while similar clinical symptoms, there is higher rate of mortality, cachexia, and degenerative changes in reproductive organs of breeding livestock. The incidence in adult animals may be up to $70 \%$ herd (6). In Akabane disease, clinical and pathoanatomical manifestations in sheep and goats are similar to those of bovines $(1,7,8)$.

The development of infection depends on virulence of the virus and the stage of embryogenesis at which occurred infestation (in the case of transplacental transmission). Infestation with Akabane virus at early stages of embryonal development, when the fetus is particularly sensitive, causes its death $(7,9,10)$. In cases of infestation at later phase of gestation, newborn calves survive, but they show polymyositis, hydrocephaly, hydroencephaly, jaundice, and skin hemorrhages.

Major changes of progeny caused by the disease are various deformities of joints and spine due to severe muscle hypoplasia. Along with physical deformities, aborted fetuses, stillborn and newborn calves show abnormalities in the central nervous system inflammatory lesions of varying degrees, neuronophagia, proliferation of glial cells $(1,9-11)$. Nonpurulent encephalomyelitis was observed mostly in the early phase of Akabane infection episode, in the second phase along with arthrogryposis there dominated 
hydroencephaly with cerebral pathology.

In cases when adult heifers and ewes get infected with Schmallenberg in the beginning of gestation, they have high probability of fetus transmission leading to lethal consequences: abortion, premature birth, stillbirth, and various developmental disabilities (6). Most often such progeny has arthrogryposis (joint stiffness, shortened tendons, twisted neck) and hydrocephaly, as well as numerous disorders of the central nervous system: paralysis, blindness, staggering gait, irritability, ataxia, inability to eat (5, 6). Aborted fetuses and newborn calves with Schmallenberg disease show pathological and morphological disturbances (12). Autopsy reveals subcutaneous hemorrhages in their head, limbs, and placenta, as well as accumulation of brown-red fluid in the brain ventricles - arthrogryposis (Fig. 2). Histological investigation show polymyositis of skeletal muscle of varying degrees.

Clinical symptoms of Schmallenberg disease differ from subclinical symptoms observed in cases of natural and experimental infestation with Akabane virus. The most severe manifestation of Akabane disease is encephalitis of adult cattle, which, according to reports, is not peculiar to Schmallenberg disease (6).
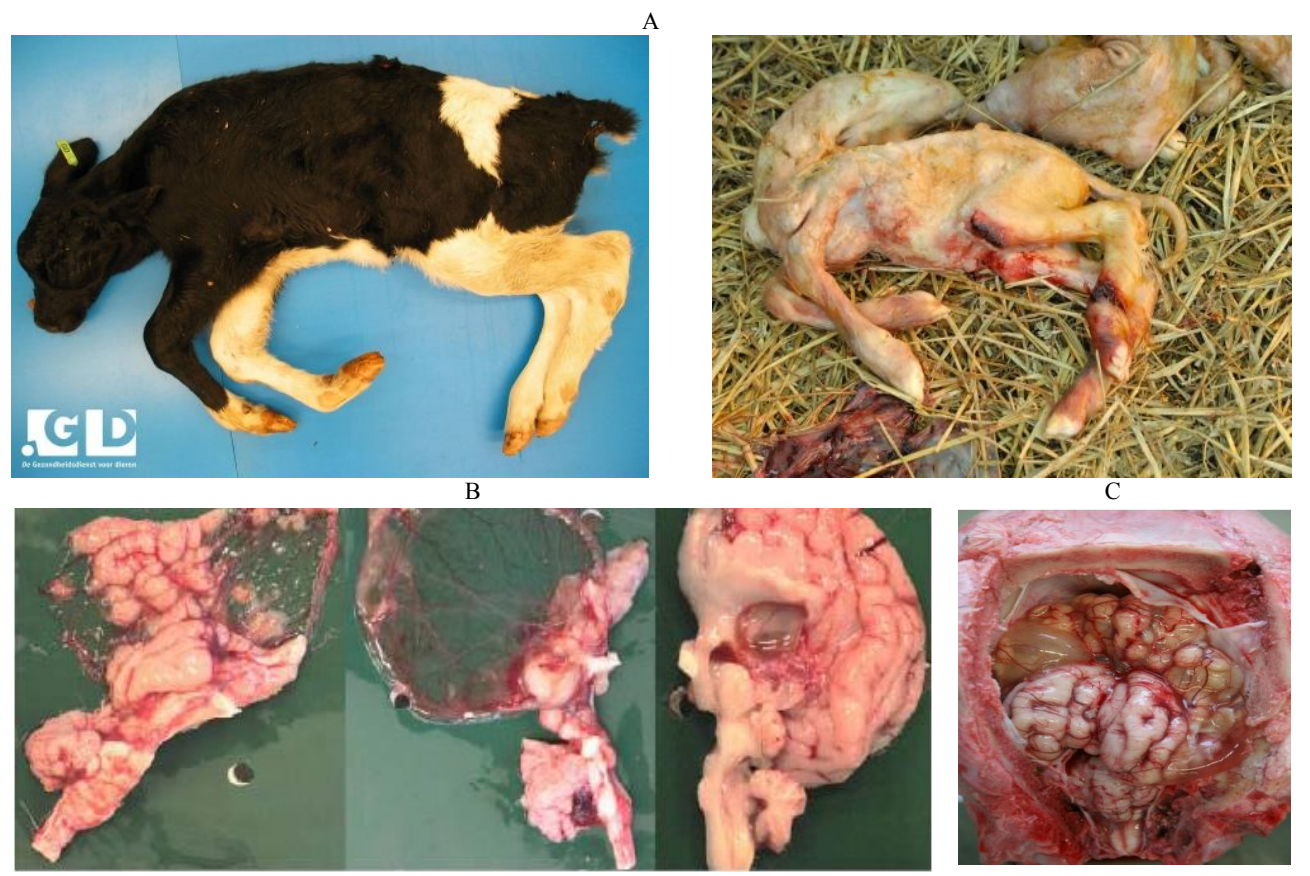

Fig. 2. Pathoanatomical manifestation of Schmallenberg disease in calves: A - arthrogryposis (cit. of http://socialvet.ru), B - abnormalities of the central nervous system (B. Hoffmann et al., 2012; cit. of 6), C hydrocephaly and cerebral hypoplasia (Martin Peters, SVUA Arnsberg, Germany; cit. of http://www.agrobiology.ru).

Akabane disease is recognized considering epizootic situation, clinical manifestations, and pathoanatomical changes, which data must be supplemented by isolation, identification, and serological verification of the virus. These investigations use biomaterial samples derived from different organs and tissues of aborted fetuses or defective progeny (brain, kidney, lymph nodes, placenta, spleen), or blood of diseased animals (1).

The diagnosis of Schmallenberg disease is based on clinical symptoms and real-time PCR identification of the viral genome (6). The tested biomaterial is blood stabilized with EDTA, or sera derived from animals with clinical symptoms of the disease (fever, diarrhea, reduced milk yield). Examination of aborted fetuses of lambs and calves with various congenital deformities is necessary, including the study of samples of brain, lung, kidney, liver, and the blood (7, 12-14).

The authors have developed the test system for real time detection of viral genomes of Akabane and Schmallenberg viruses through RT-PCR (polymerase chain reaction with reverse transcription) $(15,16)$. The method (Fig. 3) is based on amplification of DNA copies of fragments of the viral genomic S-RNA with specific oligonucleotide primers. Real-time detection of amplification products is performed using probes Taq-man labeled with fluorophores FAM (for Akabane virus) and HEX (for Schmallenberg virus). Analytical specificity of the developed test systems can be estimated on samples of heterologous RNA viruses (Nairobi disease, Ibaraki, bluetongue, Rift Valley fever), as well as intact samples. In these tests, no false-positive and false-negative results were found. Analytical sensitivity of the test system for detection of Akabane viral RNA was $1.5 \pm 0.5 \mathrm{lg} \mathrm{MLD}_{50} / \mathrm{cm}^{3}$ in the test using samples of brain tissue from intracerebrally infected mice. Analytical sensitivity of the test system for detection of Schmallenberg virus RNA was 1.33S103 DNA copies/ul in tests of 10-fold successive dilutions of the recombinant plasmid based on vector pTZ57R/T ("Fermentas", Lithuania). 
A

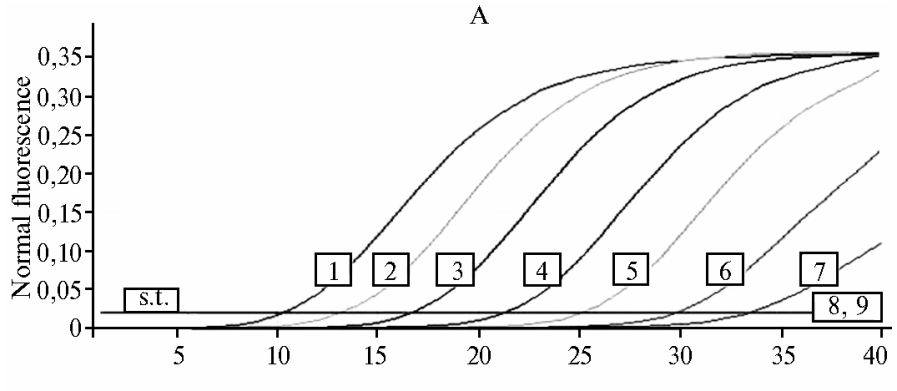

B

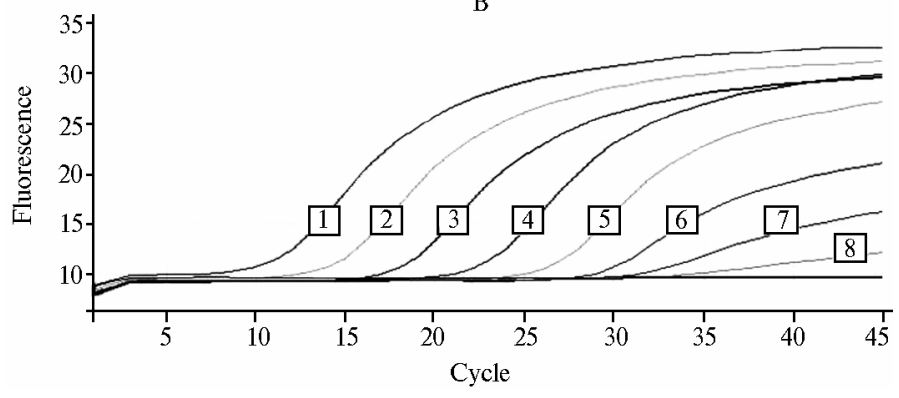

Fig. 3. Identification of Acabane viral RNA in samples of brain tissue (A) and amplification of recombinant plasmid pTZ57R/T containing the fragment of Schmallenberg virus genome (B) (sensitivity threshold - s.t.)

A: original titer of the virus $-7,5 \mathrm{lg} \mathrm{MLD}_{50} / \mathrm{cm}^{3}, 1-7-$ successive dilutions from the initial to $10^{-6} ; 8$ - negative control of isolation; 9 - negative control of PCR.

$\mathrm{B}$ : original concentration $-1,33 \mathrm{~S}^{1} 0^{11}$ DNA copies/ul, 1-8 - successive dilutions from $10^{-1}$ to $10^{-8}$.

Treatment of Akabane and Schmallenberg diseases is inadvisable (infected cattle is recommended for slaughter) (1). The spread of these diseases can be prevented by vaccination. There are effective inactivated vaccines developed in Australia, but for the most farms of Russia they are not affordable for economic reasons $(6,17)$. In epidemiologically unfavorable regions it is important to perform early serological investigation of livestock, isolation of animals with suspected disease or infection, and removal of carriers of the virus (6).

Recommendations for prevention and control of Akabane and Schmallenberg diseases suggest a number of mandatory means including quarantine and sanitary examination of animals at purchase, health monitoring of the herd, complying with all rules of disposal of dead animals, reports to veterinary services about innate defects and abortion cases, observation of clinical symptoms, preventive measures (denied access for outside persons, suspending pregnant women from work with animals, washing hands after contact with animals and especially before eating, isolations of suspect animals with symptoms of disease), health monitoring of farmers, veterinarians, and service personnel (18).

Thus, Schmallenberg and Akabane diseases have some similar traits (relative agents, clinical and pathoanatomical manifestations), as well as differences: Schmallenberg disease is more severe in sheep and goats than in bovine cattle, the duration of its viremia is 1-4 days, while in Akabane disease - 1-9 days (mostly 4-5 days); in the case of Akabane virus infection, adult diseased animals develop encephalitis, while in Schmallenberg disease such cases haven’t been observed.

\section{REFERENCES}

1. Balashova E.A. Razrabotka sredstv i metodov laboratornoi diagnostiki bolezni Akabane. Kandidatskaya dissertatsiya [Development of Means and Methods for Laboratory Diagnostics of Akabane Disease, Cand. Sci. Dissertation]. Pokrov, 1993.

2. L'vov D.K., Klimenko S.M., Gaidamovich S.Ya. Arbovirusy i arbovirusnye infektsii 「Arboviruses and Arboviral Infections]. Moscow, 1989.

3. Saeed M.F., Li L., Wang H., Weaver S.C., Barrett A.D. Phylogeny of the Simbu serogroup of the genus Bunyavirus. J. Gen. Virol., 2001 , 82(21): 73-81.

4. Sergeev V.A., Orlyankin V.G. Struktura i biologiya virusov zhivotnykh [Structure and Biology of Animal Viruses]. Moscow, 1983.

5. Syurin V.N., Fomina N.V., Samuilenko A.Ya., Solov'ev B.V. Virusnye bolezni zhvachnykh [Viral Diseases of Ruminants]. Moscow, 1989.

6. Sprygin A.V., Kononov A.V., Babin Yu.Yu., Mishchenko V.A. Sel'skokhozyaistvennaya Biologiya [Agricultural Biology], $2012,6: 24-34$.

7. Della-Porta A.J., White J.R., Gard G.P., Kirkland P.D. Akabane disease: histopathology, virology and serology. In: Australian standard diagnostic techniques for animal diseases /L.A. Corner, T.J. Bagust (eds.). CSIRO Information Services, Melbourne, 1993: 1-17.

8. Kamata H., Inai K., Maeda K., Nishimura T., Arita S., Tsuda T., Sato M. Encephalomyelitis of cattle caused by Akabane virus in southern Japan in 2006. J.

Comp. Pathol., 2009, 140: 187-193.

9. Inaba Y., Matumoto M. Congenital arthrogryposis-hydranencephaly syndrome, in virus diseases of food animals. In: Disease monographs. V. II/E.P.J. Gibbs (ed.). San Francisco, 1981: 653-671.

10. Kono R., Hirata M., Kaji M., Goto Y., Ikeda S., Yanase T., Kato T., Tanaka S., Tsutsui T., Imada T., Yamakawa M. Bovine epizootic encephalomyelitis caused by Akabane virus in Southern Japan. BMC Vet. Res., 2008, 4: 20.

11. Parsonson I.M., Mc Phee D.A. Bunyavirus pathogenesis. Adv. Virus Res., 1985, 30: 279-316.

12. Crandell R.A., Livingston C.W. Jr., Shelton M.J. Laboratory investigation of a

naturally occurring outbreak of arthrogryposis-hydranencephaly in Texas sheep. J. Vet. Diagn. Invest., 1989, 1: 162-165.

13. International society for infectious diseases, 2011-2012 (http://www.promedmail.org/index.html).

14. OIE technical factsheet/OIE, 2012 (http://www.oie.int).

15. Kolbasov D.V., Tsybanov S.Zh., Sal'nikov N.I., Nikitina E.G. Metodicheskie polozheniya po vyyavleniyu genoma virusa bolezni Shmallenberga metodom polimeraznoi tsepnoi reaktsii v real'nom vremeni [Guidelines on the Real-Time PCR Identification of Schmallenber Virus Genome]. Pokrov, 2012.

16. Kolbasov D.V., Tsybanov S.Zh., Selyaninov Yu.O., Balashova E.A., Zhabon E.O., Sal'nikov N.I. Metodicheskie polozheniya po vyyavleniyu RNK virusa bolezni Akabane metodom polimeraznoi tsepnoi reaktsii [Guidelines on PCR Identification of Akabane Virus RNA]. Pokrov, 2011.

17. Friedrich-Loeffler-Institut: Schmallenberg-Virus erstmals sichtbar gemacht (http://idw-online.de/pages/de/news467026, accessed 25.04.12).

18. Reusken C., Koopmans M. Risk profile humaan Schmallenbergvirus. National Institute of Public Health and the Environment, Bilthoven, The Netherlands, 2011. 